regard the invasion as 'liberation' with the implication that the operation was to render the population, all Japanese at that time, free, and then in the next sentence to note the number of them who fought and died trying to resist it. And the Soviet attack on the Kurils started after the Japanese surrender on 15 August. Also we have the startling proposition that John Ledyard, who participated in Cook's last expedition and who wrote an excellent account of it, was a US citizen when the expedition reached the western coast of America. As he had not set foot in what became the United States since well before the expedition departed in July 1776, he was extremely inventive in acquiring a new citizenship while serving as a Royal Marine on board a British ship. In fact, much of the phraseology in the section in question, including the probably incorrect claim that he was impressed into the Royal Navy, appears to be identical to that of the entry on Ledyard in Wikipedia, although this could, of course, be mere coincidence.

But when one examines the rest of the book, the situation becomes much better. There are authoritative sections by recognised scholars on the geology of Kamchatka, on the vegetation of the peninsula, its bird life, native peoples, etc. These are well written, informative, and a pleasure to read. One of the most interesting is by Josh Newell and is entitled 'Kamchatka; a sustainable future?' At the end he claims that 'how these revenues [arising from tourism] are being distributed remains terribly unclear' and makes the naive suggestion that visitors should ask their tour operator for a breakdown 'on how the money will be allocated and if taxes will be paid.' As if one stood the remotest chance of being told the truth! In addition, there are four interesting 'literary excerpts,' two from Steller, one from Ledyard, and one from Sten Begman's Through Kamchatka by dog sled and skis (1927).

The section entitled 'Facts for the traveller' is a reasonable and useful summary of the situation as the book went to press, but it would hardly be sufficient for those who wished to make a reasonably prolonged stay in the peninsula.

The most impressive aspect of the book is the illustrations. There are two types of photographs. The first are basically holiday snaps and were taken during the trips by the author and her friend. These illustrate the sections written by the author and do, at least, serve to relieve the tedium of the prose. The second are those taken by the professional photographers listed in the acknowledgements. These photographs are simply wonderful, by far the best this reviewer has ever seen in a travel book. There are also numerous reprints of illustrations from old works that are very interesting. The maps are well selected and informative and there are some fine Landsat images. The book is a delight to handle and to inspect and the quality of printing is excellent.

The author is to be warmly congratulated on putting all this together. It cannot have been easy to assemble the experts who have contributed to the book and to that extent the effort she made is wholly laudable. This could have been a superb book if it had been subject to tight editing under which the sections written by the author herself were reduced to a small fraction of their current length, with most of the extraneous detail omitted, and the prose tidied up, with a concomitant increase in the other much better and more informative material. An opportunity has been missed to produce a definitive book on a little known region. However, the price is so reasonable, and the quality of production so excellent, that the book is highly recommended to all with interests in the area. It is available at good bookshops or direct from www.cordee.co.uk (Ian R. Stone, Scott Polar Research Institute, University of Cambridge, Lensfield Road, Cambridge CB2 1ER.)

\section{PHOQUIERS DE LA DÉSOLATION: LA CHASSE AUX ÉLÉPHANTS DE MER AUX ÎLES KERGUELEN PAR LES NAVIRES-USINES FRANÇAIS (1925-1931). Patrick Arnaud, Jean Beurois, Pierre Couesnon, and Jean-François Le Mouël. 2007. Vachères: privately published. $268 \mathrm{p}$, illustrated, soft cover. ISBN 978-2-9530233-0-5. €21.00. \\ doi:10.1017/S0032247409008225}

Known in earlier days as the Islands of Desolation, Îles Kerguelen, named after the archipelago's eighteenthcentury discoverer, is one of the groups of French subAntarctic islands more than 2000 miles to the southeast of the Cape of Good Hope, and administered by TAAF (Terres australes et antarctiques françaises) since the midtwentieth century. The islands were a haunt of British and American sealers and the site of scientific expeditions in the nineteenth century. They were visited by Captain Scott's old Discovery during the BANZARE voyages of 1929-1931, led by Sir Douglas Mawson. This book results from the labours of the four authors, all of whom have been associated with the islands. It is a pioneering work, which chronicles the activities of the French sealers, between the World Wars, sent there by the brothers René and Henry Bossière of Le Havre, whose father Emile had obtained from the French colonial authorities in 1893 the concession for the islands for 50 years.

It is not a happy story: apart from the indiscriminate slaughter of vast numbers of sea elephants for their oil, regardless of their age and sex, the enterprise was a commercial failure, resulting in a number of fatalities, and the abandonment of several vessels. In their preface, the authors point out that their book is neither glorification nor a condemnation of the 'hunt' (la chasse) for elephant seals. Their aim has been to reveal the previously littleknown French participation in the elephant sealing trade, the product of which was oil from the rendering down of the carcasses on shore and afloat between 1925 and 1931 . They leave the reader to make his or her own judgement, but are not afraid to criticise the lack of regulations and their enforcement before and during the period concerned. To their great joy, early enquiries revealed the existence 
of a considerable number of the sealers' descendants, who kindly made their family papers and photographs available.

The text is divided into seven chapters plus references and five appendices. Black-and-white photographs appear at intervals in the text, while there are eight coloured plates, including two of the abandoned Espérance, one taken in 1970 and the other in 2002.

The first chapter provides a resume of the three campagnes (voyages) of Lozère in 1925-1926, 19261927, and 1927-1928. She had been fitted with 'autoclaves' to extract the oil from the carcasses of the seals, which was stored directly in the hold. The other half of this first chapter covers the three voyages of Austral, 1928-1929, 1929-1930, and 1930-1931. To begin with, the Bossières had envisaged following the example of the British on the Falklands in pasturing sheep on the islands, with sealing as a secondary activity. With this in mind, shepherds and their families were installed at Port-Couvreux, but with little wool being produced. Five shepherds are buried there. Another enterprise was harvesting and canning of large numbers of langoustes at Île Saint-Paul, another French sub-Antarctic island. Profitable as this was at first, leading to the recruitment of a work force from Madagascar, 42 of these died of beriberi, so that the remainder were evacuated. In this first chapter are described the origins of the sealing and other enterprises and the history of the various campagnes with their disastrous results. The wreck of Lozère on 12 February 1928, with the loss of her cargo of seal oil, and the wrecks of Espérance and Arques are described in chapter three, as well as the wreck of Dundee and MarieMadeleine, of which no trace could be found in the year 2000.

Among the factual resumes of activities on the islands - for example, ship watering, coaling, navigation, the killing of the elephant seals and the production of the resulting products - can be found the personal letters of the chief engineer André Berland to his wife during six seasons in Lozère and Austral. In the letters, he writes of his management of the engines and of the machinery for rendering down the seal carcasses for their oil, his two captains and their personalities, the assistant engineers, the passengers Monsieur E. Aubert de la Rüe (whose publications are listed in the bibliography) and his wife, the surgeons, his own experiences, and his hopes for the future. In an appendix are short biographies of Berland and other officers, followed by notes on the vessels, their crew lists, and the names of shareholders in Pêches Australes, followed by sketch maps of Kerguelen to illustrate the various zones de chasse. There is no index.

Although 'chasse' means hunting, I am reluctant to use that word - the 'chasse' was nothing but slaughter, sometimes deliberately cruel at that, especially when a poleaxe was used to kill the seals instead of a rifle. One witness is quoted on page 317 :

Et allez donc! Nos gaillards se ruent dans le tas, tuant à tour de bras. Le sang gicle, au risqué de poisser les cheveux, les barbes, les bras nus, les vêtements. Les bêtes aboient, essayant de mordre, et les hommes jurent. Bientôt, sur le charnier, un grand silence se fait. (A. Redier, 1936)

In conclusion, the authors ask, 'what traces can found today of this chasse?' The main ones are the remains of Espérance, Arques, Lozère and her boat, plus two 1931 huts at Point Morne and Point Charlotte. These last remains are destined to disappear. Existing relevant placenames are listed, followed by suggested additions.

The authors take pride in having saved from oblivion 'cette histoire qui méritait si bien d'être exhumé: une histoire d'hommes rudes et courageux qui, avec les colons de Port-Couvreux et les pêcheurs de langoustes de l'ille Saint-Paul, ont écrit, au péril de leur vie, les ultimes pages de la saga des frères Bossier' (page 237).

An omission from the bibliography is worth pointing out. It is Mme Gracie Delépine's history of the French sub-Antarctic islands, Les Îles australes françaises (1995, Rennes: Editions Ouest-France). The authors are to be congratulated on their assiduous research and on their publication of this book. (Ann Savours, Little Bridge Place, Bridge, Canterbury, Kent CT4 5LG.)

LE(S) NORD(S) IMAGINAIRE(S). Daniel Chartier (Editor). 2007. Montreal: Imaginaire Nord. 340 p, illustrated, soft cover. ISBN 978-2-923385-11-2. C \$40 or €28 doi:10.1017/S0032247409008237

The geographical delimitation of the northern realm is a well known and vexing problem, and, as is immediately shown by its title, this book does not intend to clear the point. This uncertainty or debate is somewhat indicative of the predominant role of imagination in our feelings about the north. Strangely enough, everybody has a plain opinion towards this matter regardless of whether they have been north or not.

Except for those of us who have active experience of them, the high northern polar regions, whatever the criteria used for their delimitation, are currently a matter of fear or even revulsion for those living anywhere outside (that is further south). In the conscious of most of us, cold, ice, harsh weather, poor vegetation, remoteness, and other supposedly limiting characteristics generate a definitely negative feeling of cold, solitude, mystery, dangerous adventures, hostility, technical challenge and so on. Accordingly, those visiting these regions are the beneficiaries of much admiration and respect for their supposed heroism in facing such a world of death and deprival. As a result, the involvement of men in northern exploration has always been a touchstone of national superiority.

This attitude that I would call the "southern or foreign attitude' towards the north(s) is well illustrated by the legendary sagas of the 12th-13th centuries. As pointed out by A.R. Magnusdottir, the importance given to giants and bloody and horrible massacres in those texts is consistent with the idea that unknown regions were commonly 